fingerprinting of bacteria using repetitive sequence-based polymerase chain reaction. Meth Mol Cell Biol 1994;5:25-40.

18. Woods CR, Versalovic J, Koeuth T, Lupski JR. Analysis of relationships among isolates of Citrobacter diversus by using DNA fingerprints generated by repetitive sequence-based primers in the polymerase chain reaction. J Clin Microbiol 1992;30:2921-2929.

19. Versalovic J, Kapur V, Koeuth T, et al. DNA fingerprinting of pathogenic bacteria by fluorophore-enhanced repetitive sequence-based polymerase chain reaction. Arch Pathol Lab Med 1995;119:23-29.

20. Richard C, Brisou B, Lioult J. Etude taxonomique de Levinea, nouveau genre de la famile des enterobacteries. Ann Inst Pasteur 1972:122:1137-1146.

21. Kline MW, Mason EO, Kaplan SL. Epidemiologic marker system for Citrobacter diversus using outer membrane protein profiles. J Clin Microbiol 1989;27:1793-1796.

22. Li J, Musser JM, Beltran P, Kline MW, Selander RK. Genotypic heterogeneity of strains of Citrobacter diversus expressing a 32-kilodalton outer membrane protein associated with neonatal meningitis. J Clin Microbiol 1990;28:1760-1765.

23. Shamir R, Horev G, Merlob P, Nutman J. Citrobacter diversus lung abscess in a preterm infant. Pediatr Infect Dis $J$ 1990;9:221-222.

24. Farr RW, Khakoo RA, Maxwell LP, Hill RC. Citrobacter pericarditis secondary to a subphrenic abscess. Clin Infect Dis 1994;18:838-839.

25. Booth LV, Palmer JD, Pateman J, Tuck AC. Citrobacter diversus ventriculitis and brain abscesses in an adult. J Infect 1993;26:207-209.

26. Woods CR, Versalovic J, Koeuth T, Lupski JR. Whole-cell repetitive element sequence-based polymerase chain reaction allows rapid assessment of clonal relationships of bacterial isolates. $J$ Clin Microbiol 1993;31:1927-1931.

27. Eppes SC, Woods CR, Mayer AS, Klein JD. Recurring ventriculitis due to Citrobacter diversus: clinical and bacteriologic analysis. Clin Infect Dis 1993;17:437-440.

28. Versalovic J, Koeuth T, Zhang YH, McCabe ERB, Lupski JR. Quality control for bacterial inhibition assays: DNA fingerprinting of microorganisms by rep-PCR. Screening 1992;1:175-183.

29. Versalovic J, Kapur V, Mason EO Jr, et al. Penicillin-resistant Streptococcus pneumoniae strains recovered in Houston: identification and molecular characterization of multiple clones. $J$ Infect Dis 1993;167:850-856.

30. Georghiou PR, Hamill RJ, Wright CE, et al. Molecular epidemiology of infections due to Enterobacter aerogenes: identification of hospital outbreak-associated strains by molecular techniques. Clin Infect Dis 1995;20:84-94.

31. Georghiou PR, Doggett AM, Kielhofner MA, et al. Molecular fingerprinting of Legionella species by repetitive element PCR. J Clin Microbiol 1994;32:2989-2994.

32. de Bruijn FJ. Use of repetitive (repetitive extragenic palindromic and enterobacterial repetitive intergenic consensus) sequences and the polymerase chain reaction to fingerprint the genomes of Rhizobium meliloti isolates and other soil bacteria. Appl Environ Microbiol 1992;58:2180-2187.

33. Endtz HP, Giesendorf BAJ, van Belkum A, Lauwers SJM, Jansen WH, Quint WGV. PCR-mediated DNA typing of Campylobacter jejuni isolated from patients with recurrent infections. Res Microbiol 1993;144:703-708.

34. Giesendorf BAJ, van Belkum A, Koeken A, et al. Development of species-specific DNA probes for Campylobacter jejuni, Campylobacter coli, and Campylobacter lari by polymerase chain reaction fingerprinting. J Clin Microbiol 1993;31:1541-1546.

35. Judd AK, Schneider M, Sadowsky MJ, de Bruijn FJ. Use of repetitive sequences and the polymerase chain reaction technique to classify genetically related Bradyrhizobium japonicum serocluster 123 strains. Appl Environ Microbiol 1993;59:1702-1708.

36. Leung K, Strain SR, de Bruijn FJ, Bottomley PJ. Genotypic and phenotypic comparisons of chromosomal types within an indigenous soil population of Rhizobium leguminosarum bv. trifolii. Appl Environ Microbiol 1994;60:416-426.

37. Louws FJ, Fulbright DW, Stephens CT, de Bruijn FJ. Pathovar-specific genomic fingerprints of phytopathogenic Xanthomonas and Pseudomonas strains generated with repetitive sequences and the polymerase chain reaction (rep-PCR). Appl Environ Microbiol 1994;60:2286-2295.

38. Lupski JR, Weinstock GM. Short, interspersed repetitive DNA sequences in prokaryotic genomes. $J$ Bacteriol 1992;174:4525-4529.

39. Struelens MJ, Bax R, Deplano A, Quint WGV, van Belkum A. Concordant clonal delineation of methicillin-resistant Staphylococcus aureus by macrorestriction analysis and polymerase chain reaction genome fingerprinting. J Clin Microbiol 1993;31:1964-1970.

40. van Belkum A, Struelens M, Quint W. Typing of Legionella pneumophila strains by polymerase chain reaction-mediated DNA fingerprinting. J Clin Microbiol 1993;31:2198-2200

\title{
Guidelines for Prevention of Intravascular Device-Related Infection
}

\section{by Gina Pugliese, RN, MS Medical News Editor}

A draft revision of the "Guidelines for Prevention of Intravascular Device-Related Infection" was published in the
September 27, 1995, Federal Register. Comments regarding the draft guideline may be submitted in writing by October 30 , 1995, to CDC, Attention: IV Guideline, Mailstop E-69, 1600
Clifton Rd NE, Atlanta, GA 30333. The IV Guideline Information Center at $\mathrm{CDC}$ can be reached at (404) 332-2569. 